\title{
THE FUTURE OF CONSUMER EXPERIENCE IN A SCIENCE AND TECHNOLOGY PARK - SPACES TO INTERACT
}

O FUTURO DA EXPERIÊNCIA DE CONSUMIDORES EM UM PARQUE DE CIÊNCIA E TECNOLOGIA - ESPAÇOS PARA INTERAGIR

\section{Luís Felipe Maldaner}

Ph.D. in Latin American Studies (Hankuk University of Foreign Studies/South Korea). Professor (Universidade do Vale do Rio dos Sinos/São Leopoldo).E-mail: fmaldaner@unisinos.br.

\section{Flávia Siqueira Fiorin}

Master Degree in Administration (Universidade do Vale do

Rio dos Sinos/Brasil and Universite de Poitiers/France). Project Manager (Universidade do Vale do Rio dos Sinos/São Leopoldo).E-mail:ffiorin@unisinos.br.

\section{Luísa Simon}

Master Degree in Civil Engineering ((Universidade do Vale do Rio dos Sinos/Brasil). Project analyst ((Universidade do Vale do Rio dos Sinos/São Leopoldo).E-mail: luisasi@unisinos.br. 


\section{ABSTRACT}

One of the most important value assigned to an innovation environmental is the dynamic of the network and its interaction. Concerned about that, Tecnosinos' startups were invited to evaluate and discuss the interaction and communication of the ecosystem in a Design Thinking workshop. The workshop feedback was crucial for Tecnosinos review its strategy and immediately work on the needs appointed. After the event a group actions were address considering three main approaches: communication efforts, event promotion and physical structure. Through a survey to evaluate these approaches, the startups were questioned about the expectation that entrepreneurs had before entering the Park and the experiences they had after joining the Park. As a result, the Parks have the opportunity to play the role of involving and moving the actors to a qualified interaction through its network. Tecnosinos is building, together with the startups and other actors of the ecosystem, a new consumer experience in services.

Keywords: Consumer experience. Unitec incubator. Startups. Service.

\section{RESUMO}

Um dos mais importantes valores existentes em um ambiente de inovação é a dinâmica de relacionamentos e suas interações. Nesse sentido, as startups do Tecnosinos foram convidadas a avaliar e discutir a interação e comunicação desse ecossistema num workshop de Design Thinking. O feedback coletado nesse workshop foi crucial para o Tecnosinos rever sua estratégia e imediatamente trabalhar nas necessidades apontadas pelos empreendedores. Após o evento um conjunto de ações foram iniciadas, considerando três principais pontos: esforços de comunicação, promoção de eventos e estrutura física. Através de uma survey que teve por objetivo avaliar a nova estratégia de relacionamento e comunicação, as startups foram questionadas sobre a expectativa que os empreendedores tinham antes de ingressar no Parque e as experiências que eles tiveram depois de integrar o Parque Tecnológico. Como resultado, o Parque teve a oportunidade de liderar o envolvimento e a movimentação dos atores para qualificar a interação através do network. Tecnosinos está construindo, juntamente com as startups e outros atores do ecossistema, uma nova experiência de consumo em serviços.

Palavras-chave: Experiência de consumo. Incubadora Unitec. Startups. Serviços. 


\section{INTRODUCTION}

Innovation environments, such as Parks and technology incubators, have concentrated an important part of the world's technological development. In the context of organizations that pursue collaborative networks that drive innovation, these environments have been playing an important role in promoting interaction and high-quality connections.

Policies to stimulate science and technology have expanded in recent years in Brazil. Support for the implementation and consolidation of innovation environments has been the target of public policies that encourage the implementation and consolidation of innovation ecosystems in the national territory. In Brazil, incubators as mechanisms aimed at the generation of new technology-based ventures, have the opportunity to act as strategic players into the promotion of a connection network between the startups and other actor of the innovation ecosystem (ARANHA, 2016).

The dynamic of the network and its interaction is one of the most important value assigned to an innovation environmental. The challenge is to consolidate a systematic model of information flow capable of identifying complementarity between business and technology, balancing interests and connecting markets due to promote a virtuous and sustainable interaction between the actors involved.

Assuming that STPs are a business, and resident companies and startups are clients consuming its services, the consumer experience emerges as a crucial point of view of the relation between them. In this regard, the literature cover consumer experience in terms of product or service as an individual consumer. This articles aims to cover a new point of view, which is a startup as a consumer of service in an Incubator.

From the point of view of the startups, establish at Unisinos University Incubator (Unitec), part of São Leopoldo Tech Park (Tecnosinos), this study aims to elucidate whether the experience of the startups in terms of interactions meets their expectation. The key research question explored is: How startups experience their consumption as clients of Tecnosinos? The answer will provide information suitable to guide the better allocation of Tecnosinos' resources and investments in order to improve interactions in the Park.

The paper commences with an introduction and background for the study provided by a literature review regarding consumer experience and related topics. Secondary the methodology adopted is presented. Next, it is described a series of actions promoted by Tecnosinos focused on the improvement of the interaction relations among entrepreneurs, collaborator and other actors of the innovation ecosystem and its impact on the perception of the entrepreneurs. Finally, the data resulted from a survey focus on the actions described 
are presented and analyzed. Conclusions are provided and limitations of the study are discussed before outlining areas for future research.

What are companies looking for when choosing a Science Technological Park - STP as an ideal place to set up their business? Access to highly qualified human resources from the University? Access to research? Are big companies looking for proximity with startups? Do Startups seek a collaborative environment? Do they expect to do business with large anchor companies?

\section{LITERATURE REVIEW}

In this section, this study will discuss some points related to the innovation environmental, focusing on Science Technology Parks and Incubators. A part of that, it will be mention regarding the new tendency in terms of marketing, which is the consumer experience. The especial motivation for that is the possibility to connect this new marketing theory to services provide by the Unitec Incubator to the startups. In this case, the main goal is to consider startups as a consumer of services from Unitec.

\subsection{SCIENCE TECHNOLOGY PARKS AND INCUBATORS}

The innovation environments are spaces created with the aim of supporting the continuous development of technological innovations. These environments involve the Areas of Innovation, also known in Brazil by the innovation ecosystems, and the Enterprises Generation Mechanisms. These aspects have several segments, and the STP are one of the possible types of Innovation/Ecosystem Areas of Innovation (AUDY; PIQUÉ, 2016).

In this regard, the International Association of Science Parks and Area of Innovation (IASP, 2017) defines Science and Technology Parks as an organization managed by specialized professionals, whose main aim is to increase the wealth of its community by promoting the culture of innovation and the competitiveness of its associated businesses and knowledge-based institutions. Additionally, Science Park incentives the flow of knowledge and technology among Universities, R\&D Institutions and companies. Still according to IASP (2017), it facilitates the creation and growth of innovation-based companies through incubation and spin-off processes, and provides other value-added services together with high quality space and facilities.

Science Park plays a key role in the economic development of their environment. Through a dynamic and innovative mix of policies, programs, quality space and facilities and high value-added services, they:

- stimulate and manage the flow of knowledge and technology between universities and companies;

- facilitate the communication between companies, entrepreneurs and technicians; 
- provide environments that enhance a culture of innovation, creativity and quality;

- focus on companies and research institutions as well as on people: the entrepreneurs and 'knowledge workers';

- facilitate the creation of new businesses via incubation and spin-off mechanisms, and accelerate the growth of small and medium size companies;

- work in a global network that gathers many thousands of innovative companies and research institutions throughout the world, facilitating the internationalization of their resident companies (IASP, 2017).

On the other hand, Incubator is an organization that has the objective to support entrepreneurs in order to make possible to them to develop their innovative ideas into a success business (ANPROTEC, 2017). Normally incubators offer a range of services that include infrastructure, capacitation and management support in order to increase succeed chances for the new business. A part of that, this collaborative ambient also increase possibilities of connections among all entrepreneurs of the Incubator.

In the case of technology-based startups, the entrepreneurs have, also, the opportunity to connect with Universities and Research Centers, to which the Incubator has relationship. This is a key issue to mitigate risks and to reduce costs in the innovation process, because entrepreneurs can access equipment and laboratories that are very expensive to acquire.

\subsection{SERVICES - CONCEPT AND EXPERIENCE IN SERVICES}

Service operations have assumed high level of importance nowadays and the academy has taken it as an important subject of study (CHASE; APTE, 2007). Heineke e Davis (2007) point out the significance of this theme when they related the interdependence between goods and services, because production and sell of products are in general associated to a kind of service such as transport, technical assistance, marketing and customer assistance. Bateson e Hoffman (2001) add that there is no pure service or product and it is possible to show the coexistence of both in the business relations among industrial companies, even in commercial or service companies as well.

In the literature it is possible to find differences between experience in service and services providing (BRYSON; TAYLOR, 2010), because the experience by the client is singular for each one, and it is translated into a something unique and not generalized (GONZÁLEZ, COMESAÑA; BREA, 2007). Thus the experience of consumer is related with clients' needs and principles, because this is an individual phenomenon that occurs internally (CHAG; HORNG, 2010). Additionally is important to mention that external factors such as 
culture, social issues and environmental are key for the whole context of that individual experience (GROSS; PULLMAN, 2012). It is also mentioned in the literature that the experience in services has an especial lived characteristic and it occurs before, during and after that the service occurs (ALLRED; MONEY, 2010).

Vasconcelos et al. (2012) published an article aims to systematize the concepts associated with the service experience. To do so, initially they used a systematic literature for further bibliometric analysis to identify the main articles, journals, references and keywords in order to formulate a concept of the experience of service. Figure 1 shows the map of keywords that were more significant on that research. It is possible to see that satisfaction, customer satisfaction and quality were more frequent than others were. At same time, the word "experience" emerge as a new citation on articles, not frequent as satisfaction, but it is related to that. In some sense, satisfaction was a word frequently mention as a measure of costumer relationship with service provider. Experience is a new concept in terms of services analyses and this can be a cause of that word to be less mentioned on articles.

Figure 1 - Map of words citations regarding services and consumer experience

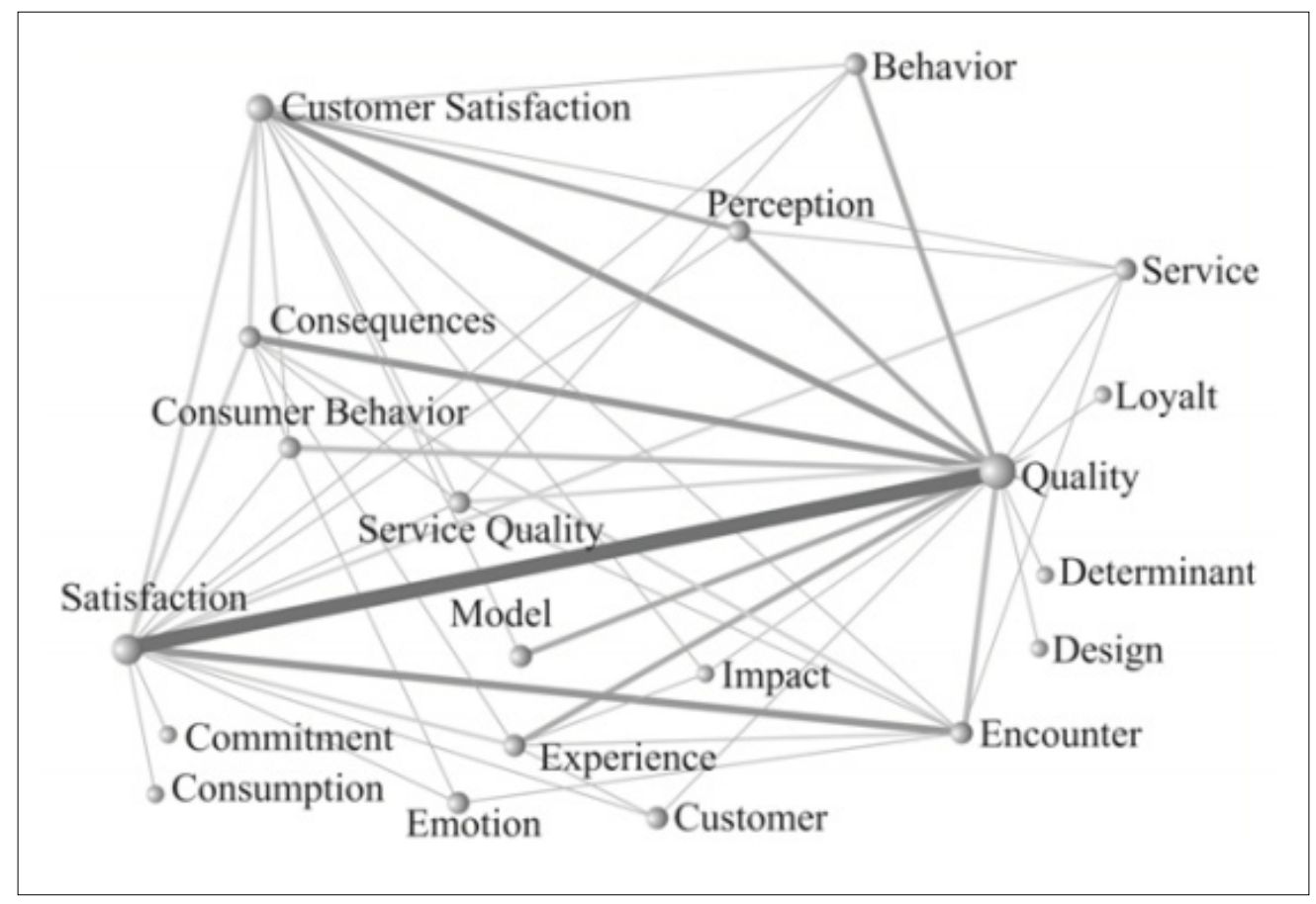

Source: Vasconcelos et al., 2012 
According to those authors, costumer experience is a cognitive, affective and behavior process, lived during de service providing, that build, or modify the image of an organization and subsidize the client buying decision process, currently and in the future. Additionally this process includes people, infrastructure and technology, influenced by clients' needs and principles, by the sociocultural context, by past experiences and by the nature and duration of the service providing.

Service experience was framed by the metaphor of processes, with the dimensions of "dispositions", "interactions" and "reactions", interdependent, complementary, which influence the quality perception and purchase decision at present and future. The lived experiences by the clients need a highlighted analysis given its strategic importance to organizations that provide services (VASCONCELOS, et al., 2012).

In the next section, this work will amplify the concept of service experience to consumer experience, which is new in that area of study.

\subsection{CONSUMER EXPERIENCE}

According to Carù and Cova (2007), consumers are not only consumers they interact according to situations. Their search for meaning and consumption is not limited to activities related to buying and post-purchase, but to experiences that extend by various stages, from the desire of consumption to the memory of the experience of consumption after it has been realized. Regarding the consumption as an experiential point of view, the authors assume that the product is not consumed by itself; the consumption is related to attend a certain function enabled by the product meaning and image.

In this context, the consumption experience surpass the moment and the purchase the point-of-sale. External and emotional relations are involved as a social economic means of socialization carried out by the imaginary and emotive aspects. The immersion in a schematized framework is part of the process of building the identity of the consumer experience.

Carù and Cova (2007) point out those consumers are not passive agents from the perspective of consumer experiences; they act within situations reacting to the stimuli and becoming actors and producers of their own consumption experience. The theaters of consumption are created to facilitate the co-production of the desired experience, in order to lead actors to meet their common expectations and interests.

The consumption experience is a complex multi-faceted phenomenon that involves objective and subjective impacts and reactions. Three levels of intervention are considered for the production of experience assigned 
by Carù and Cova (2007): multisensorial stimulation, related to physical assets like decor, design and staging; the co-production of the experience considering the consumer participation; and the storytelling created to engage the consumer into a unique and unforgettable experience process.

According to Desmet (2015) design can influence mood by enabling and stimulating people to engage in a broad range of activities. The mood design can affect motivation, behavior, and evaluation of everyday interactions. People in a good mood are more inclined to interact. Considering the interaction with a technology or an environment as an example, the mood is able to affect the kind of information that the person process. Linking to the intention of providing a specific consumer experience, the mood design is a tool that can be consider enabling relations with a positive impact.

Prahalad and Ramaswamy (2013) mention that the emergence of connected, informed, empowered, and active consumer are rapidly changing the meanings of the market dynamics. Besides that, the increase of product options also represent a challenge for managers where the creation of value has been considered critical. The direct connection between consumers, aside the company communication, also representatives challenges the impact in the creation of value. If in a near past the creation of value were mainly in charge of a firm, nowadays the intensive interaction with and between consumers are changing the traditional system where the firms used to decide the products and services they would produce. The authors also points that the interaction exceed the conventional point of sale or consumer service, it has to be consider in multiple levels.

According to the same authors, building a high-quality interaction with consumers is an opportunity to disclose sources of competitive advantages in a co-creation process. Value lies in the co-creation experience of a specific situation connected to a network. While the consumers engage in the process, the experience of this relation is becoming the locus of the value creation.

In their book "The Future of Competition", Prahalad and Ramaswamy (2013) suggest some activities or tasks that can be taken by companies in order to provide an experience opportunity to the costumers:

We can develop a broad specification for designing an experience environment. At a minimum, the experience environment must:

a) Offer opportunities for consumers to co-construct their own experiences on demand, in a specific context of space and time.

b) Accommodate a heterogeneous group of consumers, from the very sophisticated and active to the very unsophisticated and passive.

c) Recognize that every consumer (including the active, smart consumer) does not always want to co-create; sometimes he or she just wants to consume. 
d) Facilitate new opportunities afforded by the evolution of emerging technologies.

e) Accommodate the involvement of consumer communities.

f) Engage the consumer emotionally and intellectually.

g) Explicitly recognize both the social and the technical aspects of co-creation experiences (PRAHALAD; RAMASWAMY, 2013, p. 75).

Adding to the activities and tasks above, the innovation ecosystem environment, such as STP, are characterized, since its inception, by differentiated physical spaces, functional, open and shared use, that induce a new behavior of people, also encompassing spaces of coexistence and decompression, research laboratories, meeting spaces, auditoriums and other essencial business equipment (Audy and Piqué (2016). These spaces with these characteristics influence the perception of consumption in an environmental experience of the actors involved in an STP. Pardo et al. (2015) point out that one of the competitive advantages of innovation ecosystems originates precisely in the interaction of the professionals of the participating companies, thus improving their consumption experiences.

Considering the literature review, it is possible to summarize that consumer experience is how is the perception when a person is in a consume situation, either buying a physical product or consuming an intangible service.

In the follow section, it will be describe the methodology of this study.

\section{METHODOLOGY}

Design thinking has its origin in the process of designing based on creative strategies. Browm and Wyatt (2010) propose the use of design thinking as a way of reviewing not only products but also company's business models. Centered in human needs, the design thinking orientates the conception of products more serviceoriented enabling a stronger customer experience that could be converted into customer value and market opportunity.

In order to review the tecnosinos' business model related to the interaction and communication between startups and resident companies, a Design Thinking workshop was held in the park supported by a Design Thinking professional. In this workshop, Tecnosinos' startups were invited to evaluate and discuss the interaction and communication of the ecosystem. The workshop took place on July $5^{\text {th }}$ and $06^{\text {th }}, 2016$, with duration of 16 hours in total. Eight startups participated through 17 entrepreneurs and the incubator team.

Firstly, it was presented to the eight startups plus the Unitec' representatives a contextualization and explanation about what is the Design Thinking tool and about the focus of this workshop. After this initial 
stage, the participants were divided into groups to seek and make tangible solutions to the problem in question. This activity was followed by presentation of the solutions found to everyone and identification of the points in common. At that moment, the ideation phase began with the same groups from the previous activity, where the participants had to think about what would be the ideal environment for interaction and communication of the actors in the park. The participants were able to assemble their environments with blocks of assembly that allow different combinations and with modeling clay and at the end of this stage, presented their proposals everyone again.

In the prototyping stage, at the end of the second workshop day, the ideal environment was built, encompassing the strengths of each environment created in the previous stage in order to solve the problem of interaction and communication. As an immediate result of the Design Thinking workshop, the Tecnosinos Connections project was created. The event occurs monthly both inside and outside the Tecnosinos environment, and is therefore an alternative for integration in different environments. As long-term results, there is a project with logistics and infrastructure for an interaction environment within the park.

Based on the concept that one of the main values of an innovation environment is the interactions that take place in it, from the workshop results, a group of actions was addressed in order to foster the interaction between companies and entrepreneurs focusing to improve the consumer experience at Tecnosinos.

In order to validate the impact of the actions after the Design Thinking workshop, a survey was carried out. The survey considered a universe of 35 incubated startups by the incubator within Tecnosinos. This survey's objective was measuring the expectation that entrepreneurs had before entering the Park and the experiences they had after joining the Park. The questions of the first part were regarding expectations and interactions, with three alternatives of answers: "not considered", "considered" and "much considered". On the second part of the questionnaire, the questions were about their interaction with other companies and regarding their participations in events. To answer questions about participations in event it was used a Likert scale, 1 to 5 , where 1 means the worst situation and 5 the best situation. In sum, questions were directed related to participation and experience in events, dissemination of information and relationship with other companies.

The collected data were obtained through a qualitative-quantitative exploratoryapproach, using an exploratory survey based on a specific questionnaire (form attached 1), which was directed to the entrepreneurs of the startups. This questionnaire was sent through Google Docs, on line. According to Prodanov and Freitas (2013) quantitative research study aims to find the level of perception of a phenomenon within a population. Considering the 35 startups existing in Tecnosinos, the expectation of respondents was at least 30\%, in order 
to have a consistent population of analysis. The name of the companies studied will not be identified in this paper due to confidentiality, which does not compromise the reliability of the data or the development and veracity of the study.

\section{DEVELOPED ACTIONS}

When looking for a STP, companies seek an environment where they can innovate. They want to be close to the research that can be found in the University's human resources and take advantage of the business opportunities they can recognize in the startups ecosystem. The startups, seek a cool environment, access to research, mentoring, exposure to investors and large companies, and an office to call their own. However, the most relevant aspect pointed out by both types of companies is the expectation of being in a connected and quality innovation network.

Concerned Tecnosinos might be failing to provide clients with meaningful consumption experiences. The main motivation to trigger these actions was to identify and review the levels of interactions among Tecnosinos startups and propose an intervention in co-creation process in order to improve the consumer experience. Before the study launched, Tecnosinos was assuming that during the events, lectures and courses offered, companies would talk to each other and to the university. It was also assumed that a suitable environment for networking was being provided. The first action addressed pointed out that this affirmative was not completely right.

As a first initiative, a Design Thinking workshop was promoted inviting Tecnosinos' startups to evaluate and discuss the interactions and communications of the ecosystem. The result showed that they were not experiencing the interaction with the network that they expected. The major issue identified as a key experience they were not having, as much as expected, was the contact and communication between one another. On the other hand, it was possible to identify that the efforts to promote interaction done by Tecnosinos was little perceived by startups.

In fact, as in the allusion made by Carù and Cova (2007), Tecnosinos is constantly creating theaters and stages for customers to interact, but consumer experiences are not happening despite the effort of the production. By this action, a resource allocation problem was clearly identified.

The Design Thinking workshop feedback was crucial for Tecnosinos to review its strategy and investments and immediately work on the needs appointed. After the event, group actions were address considering three main approaches: communication efforts, event promotion and physical structure. 
Regarding the communication effort, the short-term actions involved the revision of the communication strategy adopted in the Tecnosinos channels and the allocation of specialized professionals to conduct the communication initiatives. From this action, the monthly newsletter structure sent to internal and external public was reviewed. The new strategy highlights the technological content developed, achievements and possible market connections of the companies installed in the Park.

The social networking approach has also been completely reformulated. Through a fan-page maintained by Tecnosinos on Facebook, the daily dynamics of the Park's ecosystem became communicated and reported. In this channel, actions, calls and other opportunities of partners related to the ecosystem are also continuously shared. By periodic reports analysis, it is possible to notice the increasing adhesion and engagement of potential customers and strategic partners to the channel. This dynamic has significantly expanded the interaction of Tecnosinos' actors with the national ecosystem of entrepreneurship and innovation. Nowadays, Tecnosinos is often sought to share information from strategic partners.

The last action to communication effort was related to internal interaction. Based on the spontaneous initiative of some entrepreneurs, Tecnosinos has adopted an online platform of communication with the startups that allows direct interaction between them and the Park administration. In this platform, channels were created together with the members by topics of interests, including groups focused on the sharing and exchange of technical information, on company profile, on human research demand, on management, on events and even on a random group for basic needs in a "friendly neighborhood" context.

The second approach was dedicated to deal with event promotion issues. Focusing on improving the startup interaction experience, besides the lectures and courses already offered by Tecnosinos, two other events were designed and promoted: Tecnosinos Connections and Meetup. The first chance in the initiative was that the events were co-created with Tecnosinos' startups, since the design unit promoted them.

The main objective of the Tecnosinos Connections is to promote relationship between the actors that integrate the ecosystem in a moment of face-to-face interaction. The directors of the 80 companies and representatives of the Park Governance are invited to the event. In happy hour style, guests are welcomed with a cocktail. After that, a formal moment of institutional presentations happens. Lasting around half an hour, a consolidated company presents a case followed by 3 pitches of incubated startups. The event continues with a dynamic of individual meetings, where the participants seek among themselves to discuss demands, technical challenges and sharing of experiences. Throughout the event, the Tecnosinos team is available to conduct approximations, but the great strength of the event lies in the spontaneity of the environment in which the entrepreneurs themselves seek their contacts. 
Tecnosinos Meetup event has the specific focus of sharing knowledge and experiences between the startups, besides promoting their connection. Inspired by the promotion of a mutual collaboration ecosystem, the Meetup is an internal technical event promoted by a Tecnosinos' startup that has as its central theme an expertise to be shared and discussed with other startups in the Park. Besides supporting the event's mobilization and operationalization, Tecnosinos' main role in the Meetup is to foster identification of topics of common interest and expertise among entrepreneurs who can promote other Meetup editions.

As an example, the first Meetup edition were promoted by an incubated startup that has experience in Amazon Web Service Solutions. Nine incubated startups participated through eighteen entrepreneurs in a deep and qualified technical discussion. One important result is that the interaction was not restricted to the event occasion. The discussion was kept in a channel created in the internal platform.

The last approach addressed as short-term action was related to physical structures. The basis for this strategic pillar was a project engaging the University's Strategic Design Graduate Program. In partnership with the Unisinos University Creative Industry, Tecnosinos designed a challenge for the master students to present new disruptive ideas that would help the Parks to promote a better communication not only between companies, but also between students, teachers and researchers. The challenge was presented to be worked on four different aspects, including intelligent communication tools and concepts and physical structures.

Considering the interaction as the focus of the project, concepts of mood design suggested by Desmet (2015) guided an evaluation of the installed structure in the Tecnosinos and the proposal of spaces interventions. The positive influence that design exerts in engaging people for an activity was explored in the proposal.

In addition to shared areas such as meeting and training rooms, Tecnosinos offers other two structures to companies: a maker space and a permanent showroom. From functionality point of view, the maker space is focused on digital and physical product prototyping, while the showroom is focused on finished products expositions. From these two extremes, the study carried out showed the need of providing an environment between these two structures, where the environmental design would promote a lightener atmosphere, mobilizing users for an extended stay, and stimulating a creative interaction between users.

To meet this objective, an area was designated to host this environment and an interior design project was developed. Funding raise for its implementation is currently underway. Besides that, as an immediate intervention "without-wall" areas were implemented by rearranging internal resources: a co-working office, where startups can work together in joint projects; meeting points for quick meeting along the circulating areas; and a mini-auditorium in an arena format. 


\section{SURVEY RESULTS AND DISCUSSION}

The survey was applied to the 35 incubated startups in Tecnosinos and it presented a return of 19 startups, representing 54\% of the population, considered adequate by the number of respondents. The presented results are divided in expectation that the entrepreneurs had before entering the Park, in the experience lived after the entrance and in the relation between these two scenarios.

\subsection{EXPECTATION}

The results about the entrepreneurs' expectation had before entering the Park were obtained through questions about the priority aspects considered as the choice to incubate in Tecnosinos. In this sense, in relation to the interaction with Unisinos University, the most outstanding aspect was the access to the qualified mentorship from professors that the university offers to the incubated companies, followed by access to the qualified human resources and by the proximity of the academic research, respectively.

When considering the expectation of interaction with other companies in the Park, as it is shown by table 1 , the exchange of experience between startups was the most considered aspect, followed by the collaborative environment between startups and the connection and possibility of doing business with other companies in the Park

Table 1 - Answers about expectation

(continua)

\begin{tabular}{|c|c|c|c|c|}
\hline & & NOT CONSIDERED & CONSIDERED & MUCH CONSIDERED \\
\hline \multirow{3}{*}{ 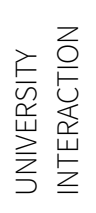 } & Access to qualified human resources & 2 & 11 & 9 \\
\hline & Access / proximity to academic research & 4 & 12 & 6 \\
\hline & Qualified Mentor & 1 & 5 & 16 \\
\hline \multirow{3}{*}{ 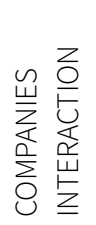 } & Collaborative environment between startups & 0 & 7 & 15 \\
\hline & Exchange of experiences between startups & 0 & 5 & 17 \\
\hline & $\begin{array}{l}\text { Connection and business with other companies of } \\
\text { the Park }\end{array}$ & 1 & 9 & 12 \\
\hline
\end{tabular}




\section{Gestãoe Desenvolvimento}

(conclusão)

\begin{tabular}{|c|c|c|c|c|}
\hline & & NOT CONSIDERED & CONSIDERED & MUCH CONSIDERED \\
\hline \multirow{4}{*}{ 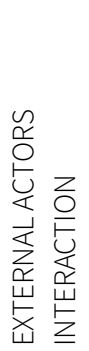 } & $\begin{array}{l}\text { Access to the network of contacts as investors } \\
\text { and / or partners }\end{array}$ & 0 & 3 & 19 \\
\hline & Access to events and calls to incubated companies & 0 & 4 & 18 \\
\hline & $\begin{array}{l}\text { Proximity/possibility of doing business with } \\
\text { consolidated companies }\end{array}$ & 0 & 9 & 13 \\
\hline & Brand recognition of the incubator and Park & 0 & 5 & 17 \\
\hline
\end{tabular}

Source: Elaborated by the authors

When questioned about the expectation of interaction with actors outside the Park, the exposure or access to the network of contact with investors or partners and access to events and calls to incubated companies was considered the most important, as it is possible to see on figure 2.

Figure 2 - Expectation about interaction

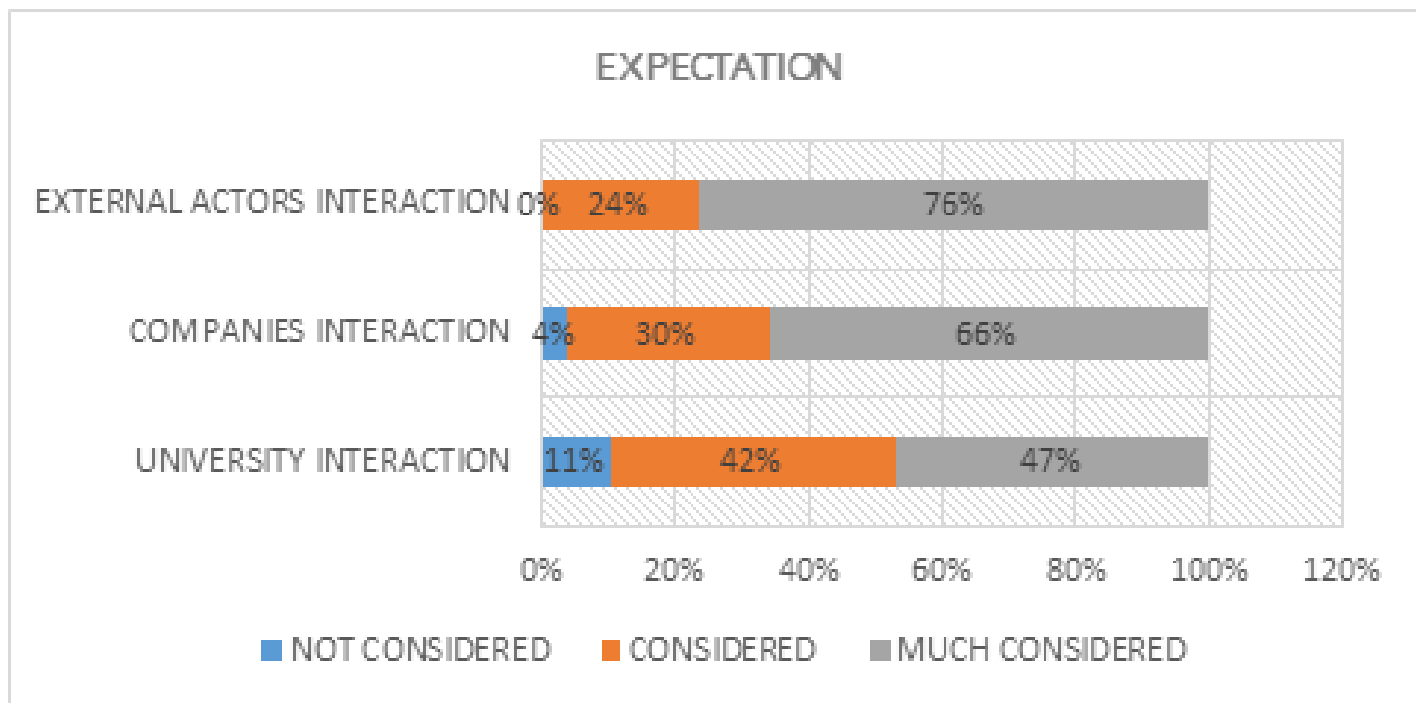

Source: Elaborated by the authors 
Next, in order of priority, it was identified the connection within the startup's ecosystem, and the visibility of the startup by the brand recognition of the incubator and the Park. Finally, the proximity and interaction with the University, and the possibility of business with consolidated companies.

\subsection{EXPERIENCE}

In this session, focused on lived experiences after installing the startup in the Park, questions regarding the experience between the entrepreneur and the startup together with the incubator and Tecnosinos. This stage of the survey was divided into experiences in general events, experiences in the Tecnosinos Connections event and experiences about the internal connections in the Park.

About the general events, the results show that $86 \%$ of the respondent incubated startups usually participate in events promoted by Technology Park. Among these companies, the strong point that motivates the participation in the events is the opportunity to interact with other companies, followed by the knowledge acquired, and finally the visibility of the business. The remaining $14 \%$ of incubated startups that do not participate in the events stated that the reasons are, respectively, availability of time to participate, theme of interest in the events offered and time at which events take place.

Considering the results about Tecnosinos Connections, entrepreneurs point out that the most significant opportunity is the exchange of information with other entrepreneurs, followed by the opportunity to learn about other companies' products and technologies, the visibility of the business and the possibility of having an idea or generate new business. Startups survey's respondents are satisfied with this event, feel that it is important, and establish relationships with other companies in the Park.

Still regarding the Tecnosinos Connections, the incubated companies were questioned as to the continuity in the relations initiated in the event. $70 \%$ of the respondents stated that yes, through sponsorship of consolidated companies of the Park, exchange of services between incubated, knowledge of the product of other startups in order to be able to indicate them in future demands, among others.

The return has been quite positive and the connections are happening. As an example, a startup that works with artificial intelligence was able to close three deals with companies in the Park that were looking for the same technology. Another startup that is developing a wheelchair established a partnership with a consolidated company interested in social projects. 


\section{Gestãoe \\ Desenvolvimento}

When questioned about how they seek to interact with other companies in the Park, it is evident that entrepreneurs prefer actions that involve personal contact, as it is shown by figure 3. The preference for interaction among people inside event comes in the second stage, followed by interactions through the online communication platform of called Slack.

\section{Figure 3 - Experience about interaction}

How do you get to know and relate with other companies at Tecnosinos?

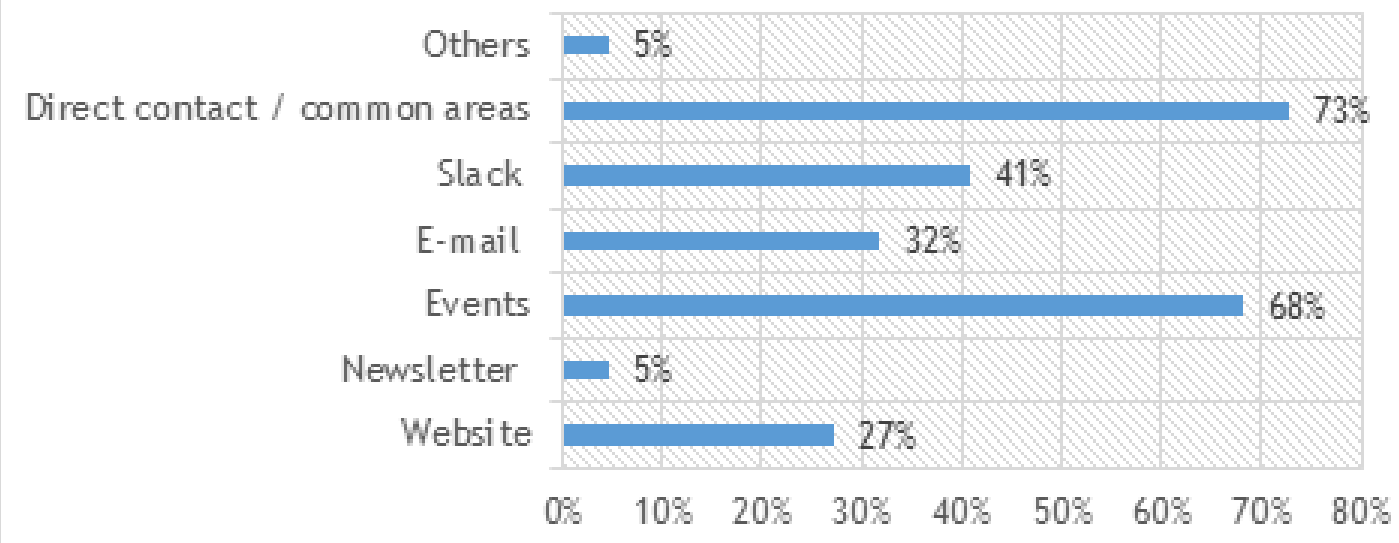

Source: Elaborated by the authors

Regarding the level of satisfaction about the Meetup technical event and Tecnosinos Connections market event, figure 4 shows that $71 \%$ and $45 \%$ of the entrepreneurs expressed great satisfaction in both events, respectively. 
Figure 4 - Events satisfaction level

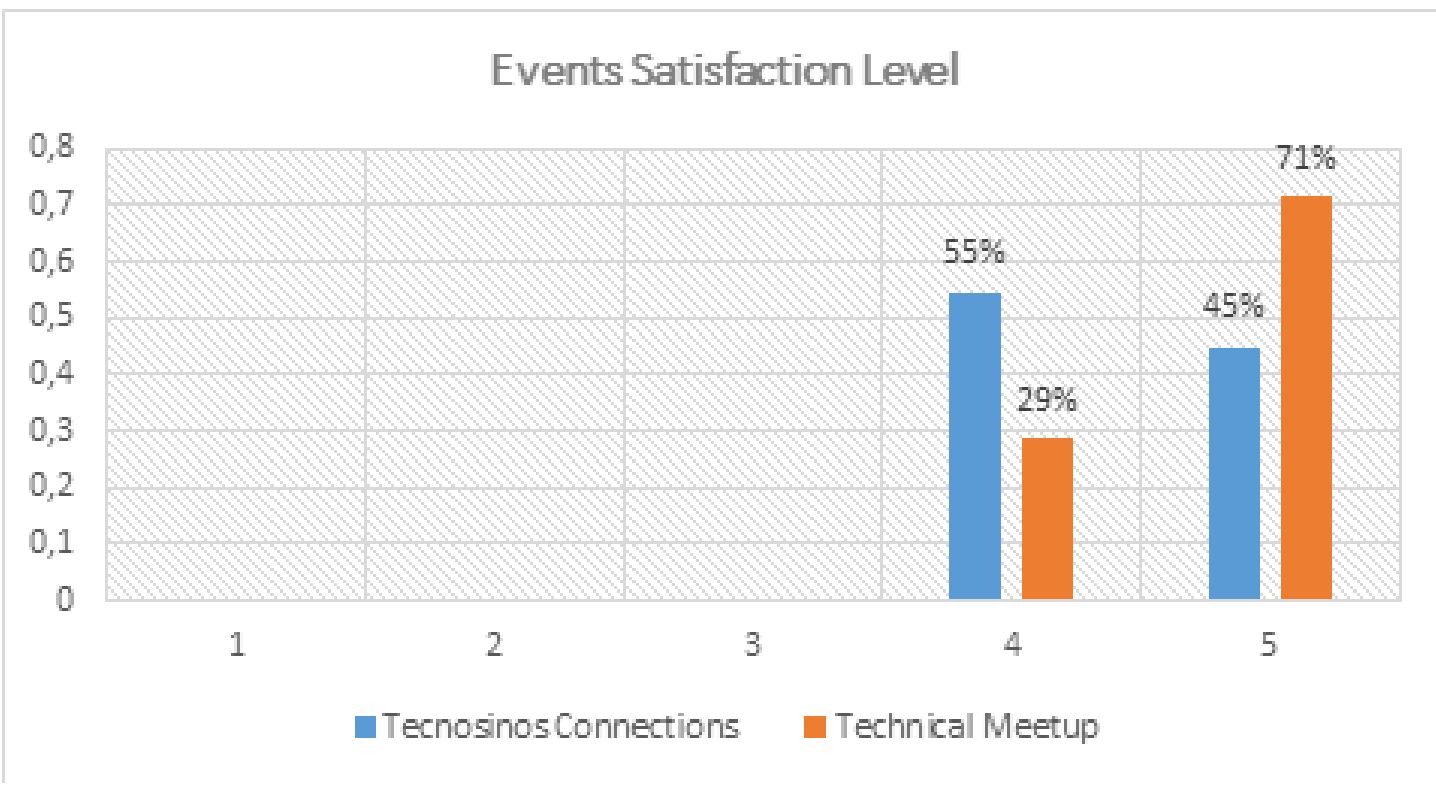

Source: Elaborated by the authors

Still on the entrepreneur's perception about the Tecnosinos Connections and Meetup events, towards the level of satisfaction, the answers about the level of relevance were also positive. Above $70 \%$ of the respondents say that these events are very relevant, as it is shown by figure 5 . 
Figure 5 - Event Relevance

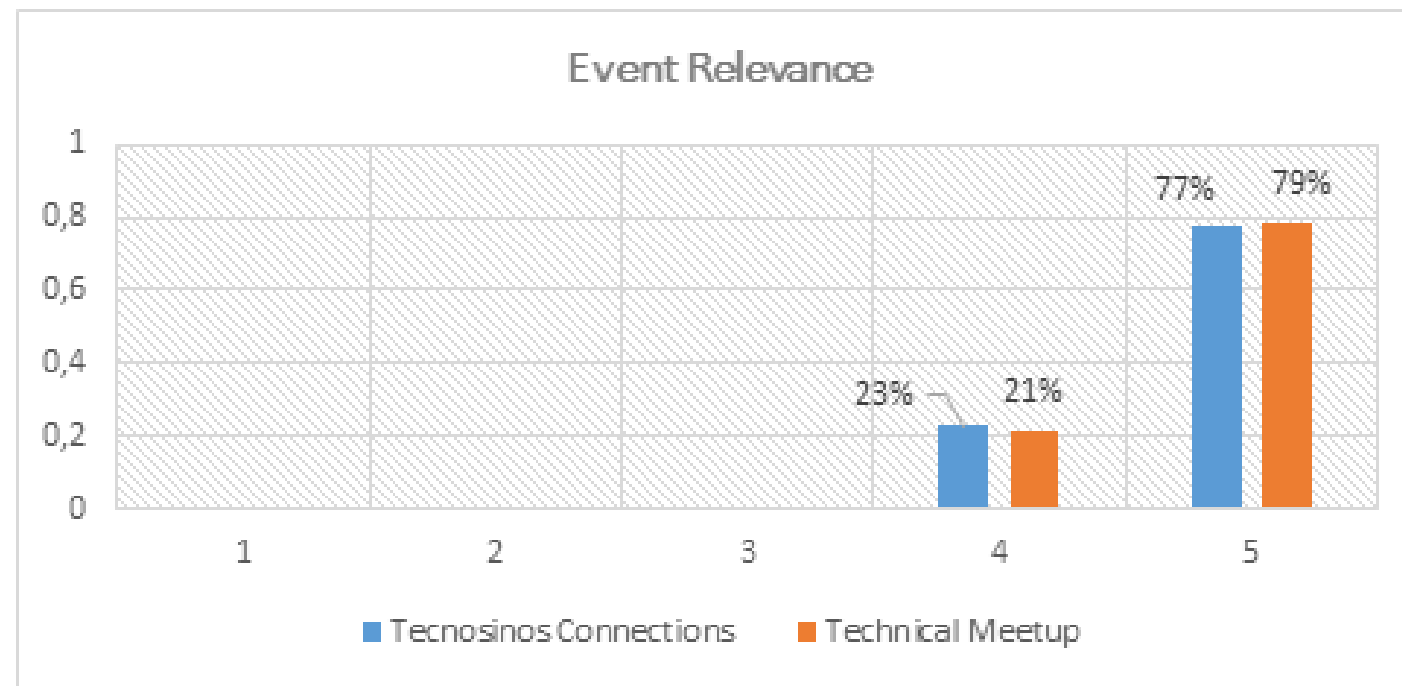

Source: Elaborated by the authors

In another question, the intention was to know if the interviewees would recommend to other entrepreneurs participation in the events promoted by Tecnosinos. All of them (100\%) said yes.

In terms of experiences with the internal connections in the Park, around $86 \%$ of the startups have relationships with other companies in the Park, whether incubated or consolidated. Among these, the most outstanding type of relationship, according to $89 \%$ of the responses, was the sharing of experience, be it market, technical or network relationship. The other relationships identified were, respectively, partnership in product development and business signed through contracting and/or sales.

In this respect, there is a strong relationship between the companies in the Park, specifically among startups. The relationships identified were based on support services for market insertion of products and product development.

\subsection{RELATION BETWEEN THESE TWO SCENARIOS - EXPECTATION AND EXPERIENCE}

It was possible to observe that, when questioned about the expectations of entering the Tecnosinos, the relations between the University and the Park were less considered. However, in the section intended to experiments, it was noticed that $27 \%$ of respondent startups have a research partnership with Unisinos and $13 \%$ have access to University's laboratories to develop their products and prototypes. 
This was an interesting result of this research, because normally expectations about relationship with University research are in high level when startups join an Incubator. In this case, it was in the opposite direction. It can be understood as an unexpected service that Unitec offers to its incubated startups.

It was possible to perceive that the experience of startups in terms of interaction meets their expectation through the exchange of experience between startups when the research showed great sharing of experience among the incubated startups evaluated.

\section{FINAL REMARKS}

At the last IASP Conference, one of the most present discussions was new business models for innovation environments and the interaction of the Parks with the city and the community. Today, the growth in demand for collaborative and coworking spaces is arising.

Assuming that the network and interaction is one of the biggest value of a Park ecosystem, Tecnosinos is reviewing its strategy of growth considering the consumer experience approach.

In the past Tecnosinos invested in expanding its physical area and building individual business modules to support the development of startups. Currently the focus is to provide spaces for them that promote visibility, sharing, cooperation and interaction between players.

Moving in the same direction, the communication and events strategy is being review. From this point of view, the entrepreneurs are being call to make part of the actions since its planning. The active participation, by sharing individual expertise and experience is being deeply fostered and promoted in a regular calendar.

Tecnosinos is working to create places with a good mood to encourage the interaction, stimulating startups to engage in a broad range of activities inside the Park enabling relations with a positive impact. In this scenario, from Tecnosinos Connections, Tecnosinos Meetup and the joint project with the Strategic Design Graduation Program, it was possible to guide the best allocation of resources and investments of Tecnosinos to improve the interactions in the Park.

In order to plan the future of the Park, the new trends must be understood. Besides listening the actors, the Parks have the opportunity to play the role of involving and moving the actors to a qualified interaction through its network. New concepts for spaces, new ideas for intelligent communication. That is what Tecnosinos is building together with the startups and other actors of the ecosystem. 


\section{REFERENCES}

ARANHA, José Alberto Sampaio. Mecanismos de geração de empreendimentos inovadores. Brasília: Anprotec, 2016.

ALLRED, C. R.; MONEY, R. B. The service hand-off: effects of multivendor service performance on customer satisfaction an experimental study. Journal of Services Marketing, v. 24, n. 2-3, p. 184-195, 2010.

ANPROTEC. ASSOCIAÇÃO NACIONAL DE ENTIDADES PROMOTORAS DE EMPREENDIMENTOS INOVADORES. Available: <http://anprotec.org.br/site/.> Access in: 07 jun. 2017.

AUDY, J.; PIQUÉ, J. Dos Parques Científicos e Tecnológicos aos Ecossistemas de Inovação. Brasília: Anprotec, 2016.

BATESON, J. E. G.; HOFFMAN, K. D. Marketing de serviços. Porto Alegre: Bookman, 2001.

BRYSON, J. R.; TAYLOR, M. Competitiveness by design and inimitability through service: understanding the dynamics of firm-based competition in the West Midlands jewelry and lock industries. Service Industries Journal, v. 30, n. 4, p. 583-596, 2010.

BROWN, Tim; WYATT, Jocelyn. Design thinking for social innovation. Development Outreach, v. 12, n. 1, p. 29-43, 2010.

CARU, Antonella; COVA, Bernard. Consuming experiences. Consuming experience, p. 34-47, 2007.

CHANG, T. Y.; HORNG, S. C. Conceptualizing and measuring experience quality: the customer's perspective. Service Industries Journal, v. 30, n. 14, p. 2401-2419, 2010.

CHASE, R. B.; APTE, U. M. A history of research in service operations: What's the big idea? Journal of Operations Management, v. 25, n. 2, p. 375-386, 2007.

DESMET, Pieter MA. Design for mood: Twenty activity-based opportunities to design for mood regulation. International Journal of Design, v. 9, n. 2, p. 1-19, 2015.

GONZÁLEZ, M. E. A.; COMESAÑA, L. R.; BREA, J. A. F. Assessing tourist behavioral intentions through perceived service quality and customer satisfaction. Journal of Business Research, v. 60, n. 2, p. 153-160, 2007. 
GROSS, M. A.; PULLMAN, M. Playing Their Roles: Experiential Design Concepts Applied in Complex Services. Journal of Management Inquiry, v. 21, n. 1, p. 43-59, jan. 2012.

HEINEKE, J.; DAVIS, M. M. The emergence of service operations management as an academic discipline. Journal of Operations Management, v. 25, n. 2, p. 364-374, 2007.

IASP - INTERNATIONAL ASSOCIATION OF SCIENCE PARKS AND AREA OF INNOVATION. Available: <https:// www.iasp. ws.> Access in: 07 jun. 2017.

PARDO, W. R; BECKER, G. V.; HANSEN, P. B.; RUAS, R. L.; MÔNEGO, H, M. The Relationship between the Competences of a Technology Park and the Competitiveness of its resident IT Enterprises: A Case Analysis at Tecnopuc. Rev. Adm. UFSM, v. 8, n. 4, p. 540-640, 2015.

PRAHALAD, Coimbatore Krishna; RAMASWAMY, Venkat. The future of competition: Co-creating unique value with customers. Harvard Business Press, 2013.

PRODANOV, C. C; FREITAS, E. C. de. Metodologia do Trabalho Científico: Métodos e Técnicas da Pesquisa e do Trabalho Científico. 2. ed. E-Book. Novo Hamburgo: Editora Feevale, 2013.

VASCONCELOS, A. M. de; BARICHELLO, R.; LEZANA, A. G. R.; FORCELLINI, F. A.; FERREIRA, M. G. G.; MIGUEL, P. A. C. Conceituação da experiência de serviços por meio de uma revisão bibliográfica sistemática. Produto \& Produção, v. 13, n. 3, p. 25-36, out. 2012. 